\title{
Analysis of Consumers' Perception at the Food Court of Lampung Walk by Using Multidimensional Scaling Approach
}

\author{
Siska Andriani ${ }^{1}$, Rosida Rakhmawati $\mathbf{M}^{2}$, Dona Dinda Pratiwi ${ }^{3}$, Feri Ariawan ${ }^{4}$, Yanuar \\ Hery Murtianto ${ }^{5}$, Bettri Yustinaningrum ${ }^{6}$ \\ 1,2,3 Universitas Islam Negeri Raden Intan lampung \\ ${ }^{4}$ Chalmers University of Techology \\ ${ }^{5}$ Universitas PGRI Semarang \\ ${ }^{6}$ STAIN Gaja Putih Takengon \\ Correspondence Address; siskaandriani@radenintan.ac.id
}

\begin{abstract}
This research aims to determine customer perceptions of food outlets located on Lampung Walk and to find out the similarities between food outlets on Lampung Walk using Multidimensional Scaling analysis. The methods used in this reseach are descriptive method and analytic survey using inferential statistics. The research places are the food outlet of Kedai Urang, el's coffee, dimsum moresto, pondok hijau and sup duren ewok. The results of this research known that the highest customer perceptions is in Kedai Urang with affordable price attributes, more portions, good taste, neat and clean presentation. So that for other business developers can pay attention to the attributes of consumer perception for business continuity.
\end{abstract}

Keywords: Analysis, Perception, Multidimensional Scaling (MDS)

\section{INTRODUCTION}

Business competition in Indonesia is growing rapidly and sharply. Every company is required to develop its business and has specific strategies in winning market competition. This makes the company carry out marketing activities, they are identifying and fulfill human need and social (Kotler \& Keller, 2009). Food business competition become one of the businesses with the highest level of competition because food is the primary need, the tendency of people to eat outside of their home is increasing with a variety of practical reason they are economic and prestige reasons. Therefore, it is very important for a restaurant to consider the restaurant strategies to create a comfortable atmosphere and able to outperform other restaurants.

Many things can be done in understanding the market conditions, one of them is by conducting market research, so that producers can fulfill the desires of their customers. This is because the continuity of the food court business is strongly influenced by consumers. The producers must be able to create new ideas and be creative and in accordance with the desired development of the consumers. Food court or in Asia Pacific is also called a food hall is a place to eat consisting of outlets that offer a variety of menus that are varied, open, informal and usually located in malls, shopping centers, offices or modern schools. Lampung Walk is a new entertainment and sports place in Bandar Lampung that provides an area of food court and Sport Center. Opinions or perceptions of consumers are very necessary to be analyzed, these opinions can take the form of an overview or map that contains about factors in the form of service to consumers, prices, tastes, types of food, presentation, cleanliness and several other supporting factors in the form of junk-food outlets, traditional Indonesian food outlets and food outlets that provide foreign food menus. The method in statistics that can solve this problem is the 
Multidimensional Scaling method, which is a method to present consumer perceptions and preferences spatially by using visible views (a visual display). Multidimensional Scaling can be used in marketing to perceive different brands in the market, also to find out the form of spatial maps where spatial maps are the relationship between the brand or other perceived stimulus, expressed as geometric relationships between points in multidimentional coordinates, shows the position or location of a brand or stimulus in a spatial map (Supranto, 2010)

Based on previous research, several studies have been conducted that analyze consumer perceptions of sales in several places (Anggara \& Wibawa, 2017; Anggraeni, Deoranto, \& Ikasari, 2015; Fitrahdini, Sumarwan, \& Nurmalina, 2013; Mayvita \& Faisal, 2016; Yunarwanto ,Yuniarinto, \& Mustajab, 2012), and studies have been conducted using the Multidimensional Scaling method. (Robbika \& Baroto, 2017). However, there hasn't been previous research that analyzed consumer perceptions using the Multidimensional Scaling method.

Based on the research that has been done before, the renewal in this research lies in the use of Multidimensional Scaling methods in analyzing consumer perceptions. So, the purpose of this research are to find out customer perceptions of food outlets on Lampung Walk and to find out the similarities between food outlets in Lampung Walk using Multidimensional Scaling analysis

\section{THE RESEARCH METHODS}

The research method used in this research is descriptive method. (Sugiyono, 2010) Primary data sources in this research were obtained from the results of questionnaires on previously determined samples, regarding the proposed indicators, secondary data obtained from secondary data obtained from informations or research results provided by units or institutions, reference books, mass media, internet, and others that support the problems (Hasan, 2013). The analysis process is then carried out on the data that has been collected so that the existing data will complement each other. The population in this research refers to all

Lampung Walk food court customers, considering the number of shops that are quite large, so the researchers took several samples from just a few food court. Respondents in this research were customers who had visited a restaurant in Lampung Walk, the number of respondents in the research were 40 respondents, where each restaurant had 8 respondents. This research uses SPSS 20 software. The observation objects studied are Kedai Urang, Dim Sum Moresto, El's Coffe, Pondok Hijau, Sop Duren Ewok

Data collection techniques which is done in this research are:

a. Questionnaire

The questionnaire in this research used open and closed questions. One way to collect data is by giving or distributing a list of questions to respondents in the hope that they will respond to the list of questions. Where the respondents were visitors to several food court on Lampung Walk.

b. Literature review

Is a method of collecting information that is relevant to research and can support and complete the data needed and useful for the arrangement of this study. 
c. Measurement of Research Instruments

This research uses a Likert scale (Likert's Summated Ratings) Likert scale to measure attitudes, opinions, and perceptions of a person types of intervals, it is a scale that shows the same scale values in the characteristics measured. (Ghozali, 2013) Here are 5 (five) assessment categories using the Likert scale

Table 2. Likert Scale Score

\begin{tabular}{ccccc}
\hline Strongly Disagree & Disagree & Undecided & Agree & Strongly Disagree \\
\hline $\mathbf{1}$ & $\mathbf{2}$ & $\mathbf{3}$ & $\mathbf{4}$ & $\mathbf{5}$ \\
\hline
\end{tabular}

The research instrument using a good questionnaire must fulfill the requirements, they are valid and reliable. To find out the validity and reliability of the questionnaire it is needed to test the questionnaire by using validity and reliability tests, because validity and reliability aims to test whether the questionnaire distributed to obtain research data is valid or reliable, therefore the authors conducted both of these tests on the questionnaire. There are three reasons researchers use the Likert scale, they are:

a. Make it easy for respondents to answer the questionnaire whether they agree or disagree.

b. Easy to use and understand by respondents.

c. Easily filled out by respondents

Table 3. Variables observed

\begin{tabular}{cl}
\hline Peubah & \\
X1 & Affordable Price \\
X3 & The food quality according to desire \\
X4 & Food Portion \\
X5 & The food variations \\
X6 & The Neatness in Serving Food \\
X7 & The Cleanness in serving food \\
X8 & The food served is always fresh and new \\
X9 & The taste of food offered is not change \\
X10 & The taste of the food that is served according to the customer's taste \\
X11 & Satisfaction with food \\
$\mathbf{X 1 2}$ & Timeliness in the presentation process \\
$\mathbf{X 1 3}$ & Friendly waiter in serving customers \\
$\mathbf{X 1 4}$ & Waiters are patient in dealing with customers \\
$\mathbf{X 1 5}$ & Skilled servants in serving customers \\
$\mathbf{X 1 6}$ & Guaranteed security \\
$\mathbf{X 1 7}$ & Restaurant cleanliness is maintained \\
$\mathbf{X 1 8}$ & Want to go back to taste thefood \\
$\mathbf{X 1 9}$ & The interior and exterior arrangement of restaurants is interesting \\
$\mathbf{X 2 0}$ & The restaurant is used as a favorite place \\
\hline
\end{tabular}




\section{THE RESULTS OF THE RESEARCH AND THE DISCUSSION}

Multidimensional Scaling (MDS) analysis is a data analysis technique used to explore data structures based on similiarity or dissimiliarity. MDS describes a set of objects as points in multidimensional spaces so that the points that have attachments between objects that have similarities are grouped together. The greater the size of the inaccuracy between the two objects, the greater the difference between the two objects so that it is more likely not to consider them in the same group, or more likely not to combine them in the same group.

Based on the scale of measurement from similarity data, MDS is distinguished by:

a. MDS metric scale

Multidimensional Scaling (MDS) metrics assume that data is quantitative (interval and ratio). In the MDS metric procedure it does not matter whether this input data is the actual distance or not, this procedure only arranges the geometry of the points of the object that are attempted as close as possible to the input distance given. So basically it is changing the distance input or metric into a geometric form as its output.

b. MDS nonmetric scale

Nonmetric multidimensional scaling assumes that the data is qualitative (nominal and ordinal). In this case the calculation of criteria is to connect the disimilarity value of a distance to the closest disimilarity value. The nonmetric MDS program uses monotonous transformations (equal) to the actual data so that arithmetic operations can be performed on the disimilarity values, to adjust the distance to the sequence value of disimilarity. Monotonous transformations will maintain a sequence values of disimilarity so that the distance between objects that is not suitable to the squence values of disimilarity is changed in such a way that it will keep fulfill the squence values of disimilarity and close to the initial distance. The results of this change are called disparities. These disparities are used to measure the level of inaccuracy in configuring objects in certain dimension maps with input data inequality. The approach that is often used today to achieve optimal results from a non-metric scale is used Kruskal's Least-Square Monotonic Transformation, where disparities are the average values of distances that is not suitable to the squence of disimilarity. Ordinal information can be processed with MDS nonmetrics so it can produce configurations of objects that are contained in certain dimensions then can make the distance between objects as close as possible to the input value of the similarity or disimilarity. The initial coordinates of each object can be obtained in the same way as the MDS metric method with the assumption that although the data is not the actual distance of information, the sequence value is seen as an interval variable.

Statistics and some terms related to scaling Multidimensional Statistics and some important terms, as follows.

a. Similarity judgments

It is the assessment (ratings) on all possibility pairs of brands or stimuli expressed in the similarity of the brands using a Likert type scale, 5 items or 7 items $(5=$ very similar, $1=$ very not similar or 7 very similar, $1=$ very not similar). 


\section{b. Preference rankings}

It is the ranking sequence of the brand or other stimulus from the most favored / favored to the most disliked.

\section{c. Stress}

It's a measure of lack of fit, the higher value of stress the more it doesn't match.

d. $\mathrm{R}^{2}=\mathrm{R}$

It is the square of the correlation coefficient which shows the variance of proportion, which is contributed by the multidimensional scaling procedure which is a measure of goodness of fit measure.

\section{e. Spatial map}

It is the relationship between the brand or another stimulus that is perceived, expressed as a geometric relationship between the points in space that are multidimensional coordinates, indicating the position of a brand or a stimulus in a spatial map (Supranto, 2010).

f. Unfolding

It is the representation of brands and respondents together as points in the same space.

Analysis of Multidimensional Scaling data uses values that describe the level of similarity or degree of dissimilarity between objects which is often called proximity (Ginanjar, 2008). Proximity is divided into two, they are:

a. Similarity

If the smaller value of the distance, it shows that the object is more similar.

b. Dissimilarity

If the greater value of the distance is, it shows that the object is increasingly different.

In some methods related to similarity, distance is intended as a measure of similarity. The size of the similarity is determined based on the distance between points. The measure of distance in a two-dimensional field can be determined using euclide distance, which is the calculation of the distance from two points in Euclidean Space. Euclidean Space was introduced by Euclid, a mathematician from Greece around 300 BC to study the relationship of angles and distances. This Euclidean is related to Pythagoras's Theorem. To calculate the value of proximity between objects on a perceptual map can be obtained by using euclid distance between the i object and the j-object:

$$
d_{i j}=\sqrt{\sum_{h=1}^{p}\left(x_{i h}-x_{j h}\right)^{2}}
$$

Matrix Centering

$$
H=\left[I-\left(\frac{1}{n}\right) J\right]
$$

with $\mathrm{J}=$ is a matrix where all the elements are 1

$$
S D=(-1 / 2) H D H=E \Lambda E^{T}
$$


Where E matrix whose corresponding eigenvector column (normalized eigenvector) corresponds to eigenvalue $\lambda$ from $((-1) / 2) \mathrm{HDH}$ and $\Lambda$ is the diagonal matrix with its main diagonal is $\lambda \_\mathrm{i}$

\section{Determination of the Main Coordinates of a Perception Map}

Perception map is a visual representation of a respondent's perception of several objects in two or more dimensions. Each object will have a spatial position on the perception map that reflects the similarity or preference to other objects by looking at the dimensions on the perception map. Perceptual map is also often called a spatial map. To obtain a perception map, the stimulus coordinate must be obtained. The MDS algorithm focuses on the fact that the $\mathrm{X}$ matrix coordinates can be obtained by the eigenvalue decomposition of the matrix scalar product. The problem in constructing $\mathrm{D}$ from the proximity $\mathrm{P}$ matrix is solved by multiplying the square of the proximity matrix with the matrix $J=I-n \wedge(-1)$ A. This procedure is called double centering.

The steps in determining the position or coordinates of the stimulus from the objects researched using the Multidimensional Scaling algorithm are as follows: (Ingwer \& Groenen, 2005)
a. Form a distance matrix (D)
b. Calculates the square of the matrix D called D2
c. Determine matrix $\mathrm{B}$ by using a double centering process

$\mathrm{B}=-1 / 2 \mathrm{JD}^{\wedge} 2 \mathrm{~J}$ : which uses a matrix $\mathrm{H}=\mathrm{I}-(1 / \mathrm{n}) \mathrm{J}$, where $\mathrm{J}$ is a matrix where all the elements are 1 , and $\mathrm{n}$ is the number of objects.

d. Take the largest 2 absolute of the eigenvalue $\lambda \_1 \ldots \lambda \_m$ on $B$ and the corresponding $m$ eigenvector e_1 ...e e_m

e. A configuration of $\mathrm{m}$-dimensional space (coordinate stimulus) for $\mathrm{n}$ objects is obtained from the coordinate matrix $X=E \_m \Lambda m^{\wedge}(1 / 2)$ where $E \_m$ is matrix of $m$ eigenvector and $\Lambda \_m$ is diagonal matrix of each $m$ eigenvalue matrix $B$.

\section{Validation of the MDS Function}

Suitability of the MDS solution is usually assessed with STRESS measures. STRESS is a measure of lack of fit, the higher the STRESS value the less suitable. In multidimensional scaling nonmetrics, only ordinal information on proximity is used to construct spatial configurations. A monotonic transformation of proximity was calculated, which produced scaled proximities. Optimally scaled proximities are also called disparities $d^{\wedge}=f(p)$

To find out the size of the lack of fit output with the actual state, the STRESS (Standarized Residual Sum of Square) function is used as follows:

$$
\text { STRESS }=\sqrt{\frac{\sum(f(p)-d)^{2}}{\sum d^{2}}}
$$

In this case: $\mathrm{d}=$ Proximity Matrix obtained by the Euclidean Distance formula. Calculation of STRESS value can also be used to assess or determine the goodness of fit in an MDS solution. A small STRESS value indicates a good match, while a high STRESS value indicates a bad 
match. Kruskal provides several guidelines for interpreting STRESS values regarding the goodness of fit of the solutions shown in Table 1 below:

Table 1. STRESS Value Criteria

\begin{tabular}{cc} 
Stress $(\boldsymbol{x})$ & Goodness of Fit \\
\hline$x \geq 20 \%$ & Worst \\
$10 \% \geq x>20 \%$ & Enough \\
$5 \% \geq x>10 \%$ & Good \\
$2,5 \% \geq x>5 \%$ & Very Good \\
$x<2,5$ & Perfect \\
\hline
\end{tabular}

The smaller the value, the monotonous relationship that is formed between inequality and disparities is getting better (obtained conformity), and the criteria for the perception map that is formed are more perfect.

Efforts are made to obtain accurate data in determining visitors' perceptions and preferences of food outlets on the Lampung Walk, so the instruments used must have a good criteria. The instruments used are tested first outside the sample in the population. Test instrument questionnaire conducted in this research is to test the validity and reliability. The trial questionnaire of this research consisted of 25 items made on 24 visitors at the food stalls. Determining whether valid or not of an item on the questionnaire is used a comparison between $r$ count and $r$ table with a significance level of 5\%, where $n=24$ then obtained $r_{-}$tabel of 0.3297 . If $r_{-}$count $\geq r_{-}$tabel, then the item is declared valid or qualifies as a good measuring instrument.

From the results of the calculation there are 5 invalid items, they are 8, 12, 18, 20, and 24, this is because $r_{-}$count $<0.3297$. Based on the criteria for statement items that will be used in retrieving data, there are 20 items of test statements that has a good criteria as items that are worthy of being used to retrieve data, it means, that the statement can be used to determine customer perceptions of food outlets on Lampung Walk.

To determine the consistency of statement items, a reliability test must be done. A test is said to have reliability if the statement item has a value of $r_{11}>r_{\text {tabel. }}$. Test reliability of statements using the Alpa Chonbach formula. Based on the reliable test that has been done, the value of $r_{11}=0.828$, then the value of $r_{11}$ is compared with $r_{\text {table, }}$, where the coefficient of $r_{\text {table }}$ is 0.349 . So that it can be concluded that $r 11>r_{\text {tabel}}$, thus the statement items have been reliable and the statement items are consistent to measure the perceptions and preferences of customers on the Lampung Walk.

\section{Multidimensional Scaling Analysis}

Analysis of customers' perceptions with Multidimensional Scaling is used to determine similar factors in food outlets on Lampung Walk. In the initial calculation, the average value of each outlet is sought with the average value of perception obtained from each attribute. Average customers' perception of 5 food outlets on Lampung Walk. Furthermore, similarity values are determined between objects by using the euclid distance formula in the form of D matrix. Thus, the similarity data is obtained in the form of the following matrix: 


$$
D=\left[\begin{array}{ccccc}
0 & 2,646 & 1 & 2 & 2 \\
2,646 & 0 & 2,449 & 2,236 & 2,236 \\
1 & 2,449 & 0 & 1,732 & 1,732 \\
2 & 2,236 & 1,732 & 0 & 1,414 \\
2 & 2,236 & 1,732 & 1,414 & 0
\end{array}\right]
$$

Rows and columns in the matrix $\mathrm{D}_{5 \times 5}$ state the research objects consisting of objects $\mathrm{A}, \mathrm{B}, \mathrm{C}$, $\mathrm{D}$, and E. From the matrix D is shown that object A and object $\mathrm{C}$ have the closest distance between other outlets with a distance of 1 . This shows that outlets $A$ and outlets $C$ have similar characteristics. While outlet A and outlet B have the furthest distance between other outlets with a distance of 2,646. Multidimensional Scaling analysis produces coordinates of points from 5 food courts, this makes easier to interpret the results in general the number of dimensions used 2 dimensions. That is as in the following table:

Table 2. MDS Analysis Dimension Table

\begin{tabular}{cccc}
\hline No & Outlets & \multicolumn{2}{c}{ Dimension } \\
\hline 1 & A & 1,3082 & $\mathbf{2}$ \\
2 & B & $-2,1022$ & 0,745 \\
3 & C & 0,9448 & 0,7162 \\
4 & D & $-0,0754$ & 0,4963 \\
5 & E & $-0,0754$ & $-0,932$ \\
\hline
\end{tabular}

From table 2 above it is known where the coordinates of each outlet are in dimension 1 ( $\mathrm{X}$ axis) and dimension two ( $\mathrm{Y}$ axis). Outlet A is located at the coordinates (1.3082, 0.745). Outlet B is located at the coordinates $(-2.1022,0.7126)$. Outlet $\mathrm{C}$ is located at coordinates $(0.9448,0.4063)$, Outlet $\mathrm{D}$ is located at coordinates $(-0.0754,-0.932)$ and outlet $\mathrm{E}$ is located at coordinates ($0.0754,-0.932$ ). Based on the coordinates of the points obtained in Table 4.4, the spatial or perceptual map is obtained as follows:

Derived Stimulus Configuration

Euclidean distance Model

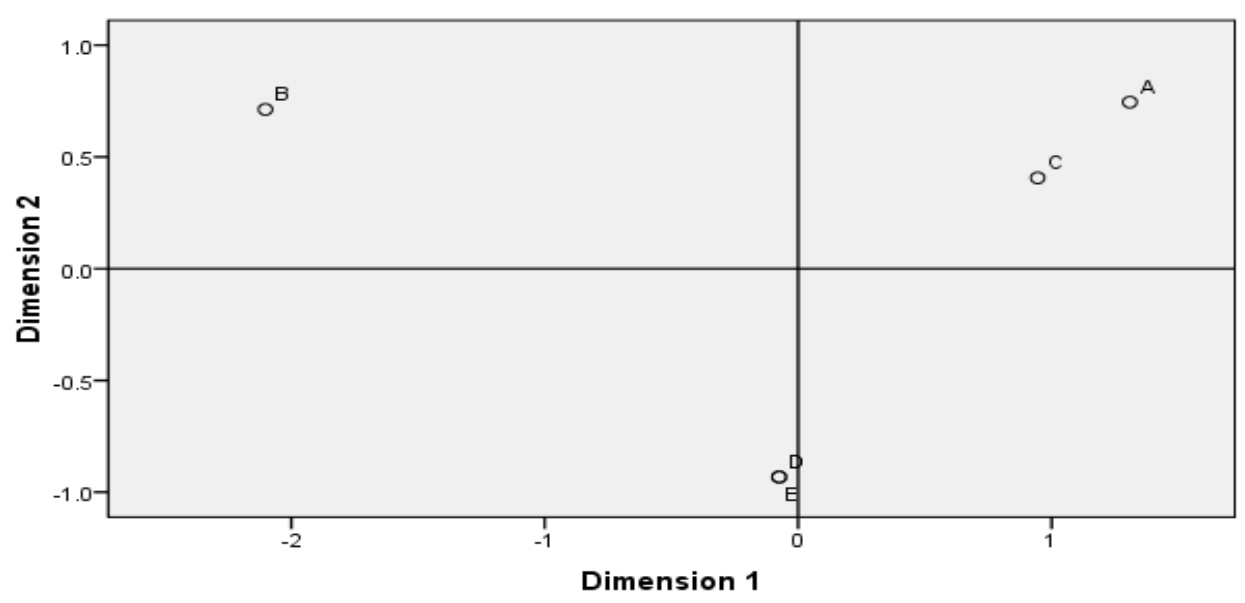

Picture 1. Dimensional Scaling Results for Each Outlet along with Outlet Characteristics 
The Spatial Map above shows similarities and dissimilarities between one outlet and other outlets based on the quadrant. The outlets in one quadrant have similar characteristics. From picture 4.1, it can be seen that outlet $A$ and outlet $C$ are located in quadrant 1. Outlet $D$ and outlet $\mathrm{E}$ are located in quadrant 3 . And outlet $\mathrm{B}$ is located in quadrant 4 . Location of similarity of each object is seen in the spatial map illustrated in Figure 4.2 below:

The Spatial Map above shows similarities and dissimilarities between one outlet and other outlets based on the quadrant. The outlets in one quadrant have similar characteristics. From picture 4.1, it can be seen that outlet $A$ and outlet $C$ are located in quadrant 1. Outlet $D$ and outlet $\mathrm{E}$ are located in quadrant 3 . And outlet $\mathrm{B}$ is located in quadrant 4 . Location of similarity of each object is seen in the spatial map illustrated in picture 4.2 below:

\section{Derived Stimulus Configuration}

\section{Euclidean distance Model}

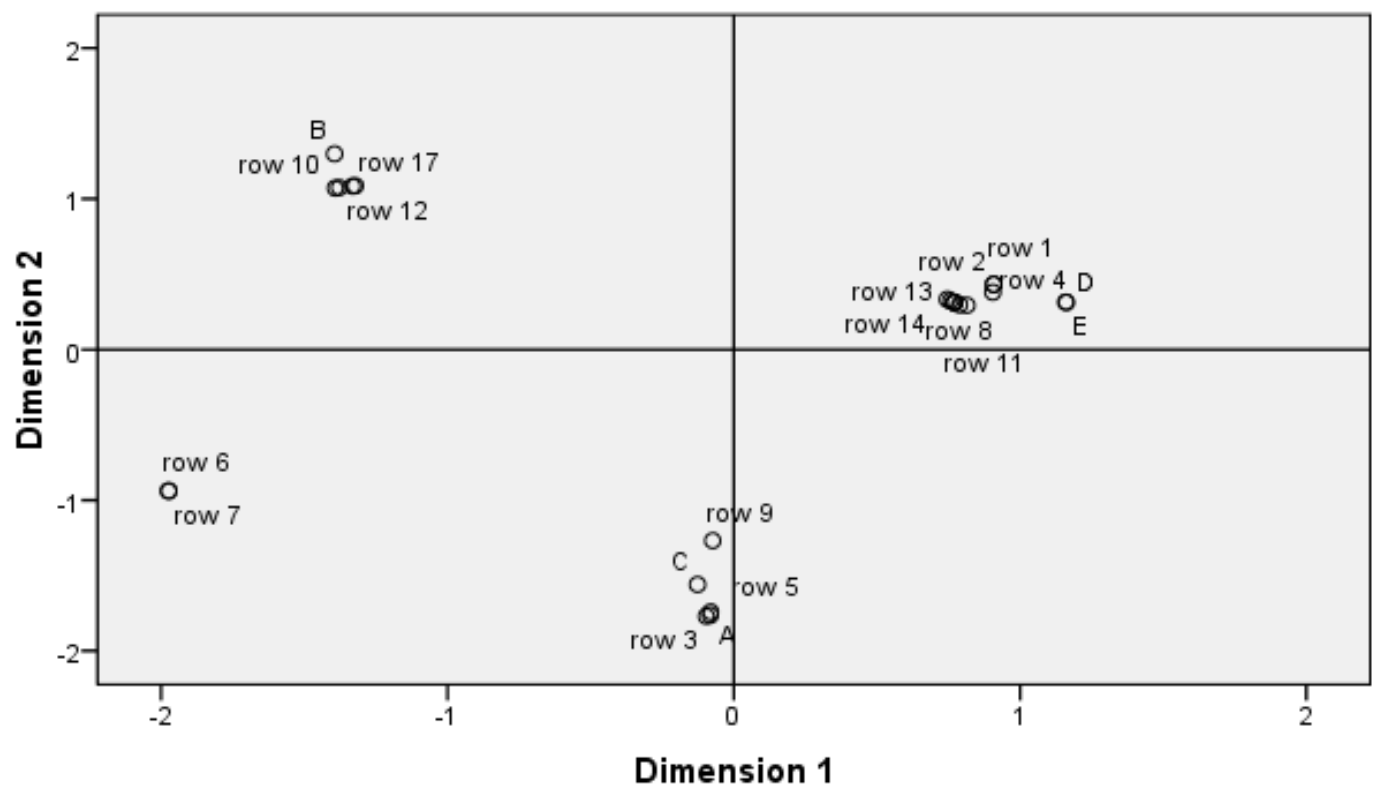

Picture 2. Dimensional Scaling Results for Each Outlet along with Outlet Characteristics

The scaling results in picture 4.2 show that outlets located in the same quadrant have similarities in some attributes. Outlet $\mathrm{A}$ and outlet $\mathrm{C}$ have similarities to attribute number 3, number 5 , number 6 , number 7 , and number 9 . Outlet $\mathrm{D}$ and outlets $\mathrm{E}$ have similarities to attribute number 1 , number 2 , number 4 , number 8 , number 11 , number 13 , and number 14 .

The calculation results of the STRESS value are obtained at 0.05377 or around $5.37 \%$. This means that the spatial map or Multidimensional Scaling scoring model obtained is included in a good criteria. Furthermore, the calculation of $R^{2}$ is obtained that the value of $R^{2} 0.98$ or $98 \%$ this shows that the spatial map obtained is acceptable

Based on the results of the Multidimensional Scaling analysis process from 40 people who became reasearch's sample it is known that :

1. Outlet $\mathrm{A}$ and outlet $\mathrm{C}$ have similarities to attributes number 3 , number 5 , number 6 , number 7 , and number 9 . This means that the outlets $\mathrm{A}$ and $\mathrm{C}$ have similarities in terms of:

a. More food serving 
b. The foods are high in taste

c. The presentation of food is neatly arranged

d. Food serving is too clean

e. The taste of food offered does not change

2. Outlet $\mathrm{D}$ and outlet $\mathrm{E}$ have similarities to attributes number 1, number 2, number 4, number 8 , number 11 , number 13 , and number 14 . This means that the $\mathrm{D}$ and $\mathrm{E}$ outlets have similarities in terms of:

a. The price offered is affordable

b. The quality of food is given as desired

c. The type of food varies

d. The food served is always fresh and new

e. Very satisfied with the food provided

f. Friendly waiter in serving customers

g. Waiters are patient in dealing with customers.

Mathematics in business life is used as a medium or tool to simplify the presentation and understanding of problems where by using the language of mathematics, the problems that exist in the business world can be simpler to be presented, understood, analyzed, and solved. Mathematical concepts are very important in the business to analyze a problem and function to form relationships between these variables in the form of mathematical equations, so they can be tested empirically. This research is in line with the development of a business center that will be developed by UIN Raden Intan Lampung so that this research can indirectly contribute to market conditions and how patterns should be developed in the business center will be built.

\section{CONCLUSION AND SUGGESTION}

Based on the results of research that has been done, it can be concluded that customers' perceptions of food outlets are seen from 20 types of attributes, they are Kedai Urang outlets, based on the results of data processing with Multidimensional Scaling (MDS). It can be seen that Kedai Urang is in the same quadrant as El's coffee., so that these two outlets have similarities to some attributes such as the portion of food served are more, the food available is high in taste, the presentation of the food served is neat, the presentation of food is too clean, and the taste of food offered is not change. Furthermore, in the Pondok Hijau outlet and sop duren ewok are in the same quadrant, so that these two outlets have similarities to some attributes such as affordable prices offered, the quality of food provided according to wishes, types of food are in vary, food served is always fresh and new, very satisfied with the food provided, friendly servants in serving customers, and patient waiters in dealing with customers Based on the conclusions of this research, it can be proposed a number of suggestions for further researchers, expected to be able to examine the problem with a broader range, which can try to use other methods to analyze perceptions and other things from consumers.

\section{REFERENCES}

Anggara, F., \& Wibawa, B. M. (2017). Analisis Strategi Positioning Merk Berdasarkan Preferensi, Persepsi, dan Kepuasan Konsumen Produk Pertamina Lubricants. Jurnal 
Teknik ITS, 5(2), 1-10.

Anggraeni, L. D., Deoranto, P., \& Ikasari, D. M. (2015). Analisis Persepsi Konsumen Menggunakan Metode Importance Performance Analysis dan Customer Satisfaction Index. Industria : Jurnal Teknologi Dan Manajemen Agroindustri, 4(2), 74-81.

Fitrahdini, Sumarwan, U., \& Nurmalina, R. (2013). Analisis Persepsi Konsumen Terhadaap Ekuitas Merek Produk Es Krim. Jurnal Ilmu Keluarga Dan Konsumen, 3(1), 74-81.

Ghozali, I. (2013). Analisis Multivariat dengan Program IBM SPSS 21 (7th ed.). Semarang: Universitas Diponegoro.

Ginanjar, I. (2008). Aplikasi Multidimensional Scaling (MDS) Untuk Peningkatan Pelayanan Proses Belajar Mengajar (PBM). Bandung: Staf Pengajar Jurusan Statistika FMIPA UNPAD.

Hasan, M. I. (2013). Analisis Data Penelitian dengan Statistik (II). Bumi Aksara.

Ingwer, B., \& Groenen, P. J. . (2005). Modern Multidimensional Scaling: Theory and Applications (Second Edition). New York: Springer.

Kotler, P., \& Keller, K. L. (2009). Manajemen Pemasaran Jilid 2 (13th ed.). Jakarta: Erlangga.

Mayvita, P. A., \& Faisal, I. (2016). Analisis Positioning Restoran Cepat Saji Waralaba Fried Chicken di Banjarmasin ( Studi Pada KFC Duta Mall, Texas Fried Chicken Duta Mall, AW Duta Mall, Mall dan California Fried Chicken RS Ulin Banjarmasin). JWM : Jurnal Wawasan Manajemen, 3(1), 33-44.

Robbika, A. A., \& Baroto, T. (2017). Perencanaan Strategi Pemasaran Dengan Metode Multidimensional Scalling Dan Quality Function Deployment. Jurnal Teknik Industri, 17(1), 12-21.

Sugiyono. (2010). Metode Penelitian Pendidikan Pendekatan Kuantitatif, Kualitatif, dan R \& $D$. Bandung: Alfabeta.

Supranto, J. (2010). Analisis Multivariat: Arti dan Interprestasi. Jakarta: PT. Rineka Cipta.

Yunarwanto, D., Yuniarinto, A., \& Mustajab, M. (2012). Analisis Posisi Persaingan Operator Telepon Seluler Berdasarkan Persepsi Konsumen di Kota Malang. Wacana : Jurnal 